University of Michigan Law School

University of Michigan Law School Scholarship Repository

1919

\title{
The Writing Required to Establish an Express Trust of Land
}

Edgar N. Durfee

University of Michigan Law School

Available at: https://repository.law.umich.edu/articles/986

Follow this and additional works at: https://repository.law.umich.edu/articles

Part of the Estates and Trusts Commons, and the Property Law and Real Estate Commons

\section{Recommended Citation}

Durfee, Edgar N. "The Writing Required to Establish an Express Trust of Land." Mich. L. Rev. 17 (1919): 266-8.

This Response or Comment is brought to you for free and open access by the Faculty Scholarship at University of Michigan Law School Scholarship Repository. It has been accepted for inclusion in Articles by an authorized administrator of University of Michigan Law School Scholarship Repository. For more information, please contact mlaw.repository@umich.edu. 
The WRIting Reguired to Establish an Express Trust of Land.-It has frequently been said that the Seventh Section of the Statute of Frauds, concerning Trusts of land, requires a writing containing "all the terms of the trust." Forster v. Hale, 3 Ves. 707; Smith v. Matthews, 3 DeG., F. \& J. 130; Loring v. Palner, I18 U. S. 321; Gaylord v. Lafayette, II5 Ind. 423; McClellan v. McClellan, 65 Me. 500; Blodgett v. Hildreth, I03 Mass. 484; York v. Perrine, $7 \mathrm{I}$ Mich. 567; Newkirk v. Place, 47 N. J. Eq. 477; Steere v. Steere, 5 Johns. Ch. I; Cook v. Barr, 44 N. Y. I56; Dillaye v. Greenough, $45 \mathrm{~N}$. Y. $438 ; D_{3} \in r^{\prime}$ 's Appeal, $107 \mathrm{~Pa} .446 ;$ McCandless v. Warner, $26 \mathrm{~W}$. Va. 754. This doctrine comes to the test in a case where there is a writing, signed by the person who is enabled to declare the trust, sufficiently identifying the land, and declaring that it is held in trust, but without naming the beneficiaries or otherwise failing to meet the stated requirement, but where parol evidence sufficiently establishes the terms of the trust to enable the court to enforce it if the Statute does not prevent. In such a case, does the Statute render the trust unenforcible? It is submitted that it does not.

The policy of the Statute of Frauds is to prevent frauds through perjury, not generally but in particular classes of cases, selected and defined. we must assume, upon the theory that such frauds are more likely in these than in other cases, or would in these, if perpetrated, be more than commonly obnoxious, or that, in these cases, the imposition of the statutory requirements upon an honest claimant would involve less than ordinary hardship. The method adopted to prevent such frauds in such cases is to relieve the putative victim from the necessity of meeting and disproving a claim supported only by parol, and presumably perjured, evidence, requiring in such cases higher evidence, usually a writing over the signature of the putative victim. The Statute is extremely concise, considering the complexity of the problems touched by it, and leaves much to judicial interpretation, as to the cases embraced, the character of the writing required, and otherwise. Such interpretation should obviously proceed with the policy of the Statute clearly in view.

The provisions touching trusts of land would seem to be designed to protect the beneficial owner from expropriation by judicial proceedings based on perjured parol evidence of a declaration of trust. If this be so, the only writing required to effectuate the policy of the statute is one identifying the land and clearly indicating that the person alleged to be a trustee has no beneficial interest therein, or only a specified interest. This position is squarely denied in Smith v. Mattheres, supra. There counsel argued, "the 
danger to be guarded against is the defrauding a man by establishing him to be a mere trustee on parol evidence," to which Turner, L. J., replied, "The statute was intended to guard against perjury as well as frand. You let in the risk of perjury as between cestuis que trust." With due respect, it is submilted that this dictum (for such it was) involves an unwarranted assumption as to the policy of the Statute, and produces the absurd result of preventing perjury among the contending cestuis, some of whom, by hypothesis, are entitled to the property, by taking the property from them all and giving it to the trustee, who has, by an adequate writing, been shown to have no beneficial interest. This sort of justice savors too much of Aesop's fables. Our case is distinguishable from that arising under the provision concerning contracts. There it may well be sound policy, and therefore presumably the intent of the statute, to require that the writing contain all the terms of the contract. Else, one who has been so ill advised as to sign a memorandum showing merely that there is a contract might have a confiscatory bargain thrust upon him by perjury. We might say that the normal contract case is like the exceptional trust case where there is a trust as to a partial interest only, the trustee being beneficial owner in part, in which case it seems essential that the writing show the trustee's interest, or, to put it the other way, the extent of the trusteeship. In both cases the putative victim of the putative fraud may be as vitally concerned with certain terms of the contract or trust as with its existence. Distinctions might also be based upon differences of phraseology between the fourth and the seventh sections of the Statute, but, as the language is not explicit in either, policy seems to be surer ground.

The cases cited above, as asserting that the writing must contain all the terms of the trust, prove upon scrutiny to be but slight authority for that doctrine. In several of them, the court would have reached the same conclusion without any statute, because it found that the evidence, written and parol, was, at most, ambiguous and insufficient to raise the burden of proof. In Dillaye v. Greenough, there was apparently no evidence whatever, either written or parol, to identify the beneficiaries. In others of the cases, though the parol evidence might have established a trust, the writing was inadequate under any theory, containing but the remotest hint that there might be a trust, or indicating but a promise, without consideration, to create a trust, or failing to identify the subject matter, under which last head may be ranged those cases where a parcel of land was identified but it appeared that the trustee had some beneficial interest and the writing did not disclose the extent of the trusteeship. Again, in several of the cases the doctrine was not applied, the trust being established and enforced upon a finding that the writing satisfied the stated requirement. But, of these last mentioned cases, two would seem to be, upon their facts, authorities against their own dicta, and even to go beyond the position here advanced. Such, are Loring v. Palmer and Nezukirk v. Place. In the latter the writings contained no description, formal or informal, of the land, but the court relied upon admissions at the hearing that they referred to the land in question. It is obvious that this goes far beyond the disputed doctrine that an answer admitting the trust 
is a sufficient writing, though it pleads the statute as a defence, and it is also obvious that a similar ruling would not be made upon a parallel case of contract of sale. In the former case, the court pieces together several writings which are not connected within the principle of incorporation by reference, and even then finds itself faced by the case of a trustee with a beneficial interest, the extent of which does not appear in the writings, from which position it purports to find escape by means of a "presumption" that the shares were equal. One has only to consider what the court would have done if the parol evidence, instead of indicating equal shares, as it did, had indicated a different proportion, to see that the presumption theory was of the nature of a beneficent fiction indulged to avoid the necessity of taking bolder ground. To these cases we may add two Illinois decisions which franikly accept the theory here maintained. Kingsbury v. Burnside, 58 Ill. 310; Myers v. Myers, 167 Ill. 52 . See also, Railroad v. Durant, 95 U. S. 576 , and cases cited by Browne, STATUTE of FraUds, § III. The only clear authority to the contrary seems to be Dyer's Appeal, supra. It is therefore submitted that authority, as well as principle, is opposed to the doctrine that all the terms of the trust must be contained in the writing.

It should be noted that the acceptance of that doctrine would be much more serious in this country than in England, because of onr conservatism upon the raising of constructive trusts to prevent unjust enrichment through the breach of parol trusts. I2 MicH. L. REv. 423, 5I5; 28 HaRv. L. REv. 237,366 . 